\title{
The FB-Line and F-Canyon HAN/Nitric Acid Decomposition Study
}

by

T. Hang

Westinghouse Savannah River Company

Savannah River Site

Aiken, South Carolina 29808
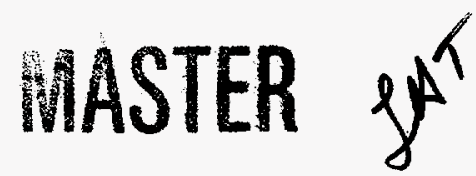

\section{DASTREUTION OF THIS DOCUMENT IS UNLMITED}

DOE Contract No. DE-AC09-96SR18500

This paper was prepared in connection with work done under the above contract number with the U. S. Department of Energy. By acceptance of this paper, the publisher and/or recipient acknowledges the U.S. Government's right to retain a nonexclusive, royalty-free license in and to any copyright covering this paper, along with the right to reproduce and to authorize others to reproduce all or part of the copyrighted paper. 


\section{DISCLAIMER}

This report was prepared as an account of work sponsored by an agency of the United States Government. Neither the United States Government nor any agency thereof, nor any of their employees, makes any warranty, express or implied, or assumes any legal liability or responsibility for the accuracy, completeness, or usefulness of any information, apparatus, product, or process disclosed, or represents that its use would not infringe privately owned rights. Reference herein to any specific commercial product, process, or service by trade name, trademark, manufacturer, or otherwise does not necessarily constitute or imply its endorsement, recommendation, or favoring by the United States Government or any agency thereof. The views and opinions of authors expressed herein do not necessarily state or reflect those of the United States Government or any agency thereof.

This report has been reproduced directly from the best available copy.

Available to DOE and DOE contractors from the Office of Scientific and Technical Information, P. O. Box 62, Oak Ridge, TN 37831; prices available from (423) 576-8401.

Available to the public from the National Technical Information Service, U. S. Department of Commerce, 5285. Port Royal Road, Springfield, VA 22161. 


\section{DISCLAIMER}

Portions of this document may be illegible in electronic image products. Images are produced from the best available original document. 
Keywords: HAN

Retention: permanent

cc: W.L. Tamosaitis, 773-A

W.E. Stevens, 773-A

B.T. Butcher, 773-43A

E.A. Kyser, 773-A

F.R. Graham, 773-A

J.B. Schaade, 703-F

T.G. Campbell, 221-F

W.E. Harris, 221-F

R.L. Yourchak, 703-F

B.V. Nguyen, 703-F

SRTC Records (4), 773-52A

Technical Review:

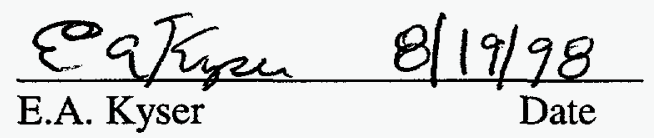

\section{9-August-1998}

TO:

W.B. Van-Pelt, 679-T

FROM:

Thong Hang, 773-42A<smiles>C1CCCC1</smiles>

\section{THE FB-LINE AND F-CANYON HAN/NITRIC ACID DECOMPOSITION STUDY (U)}

\section{SUMMARY}

Separations requested SRTC study the autocatalytic decomposition of the hydroxylamine nitrate (HAN) which may occur in the presence of concentrated nitric acid with respect to making-up cold feed solutions. The data obtained from this study will provide Separations an envelope within which safe operations can be conducted.

The Parr® 1455 solution calorimeter was used to measure the energy change due to decomposition at room temperature. Tests were carried out using $64 \mathrm{Wt} \%$ nitric acid which was diluted to $0.1 \mathrm{M}, 0.25 \mathrm{M}$ and $0.5 \mathrm{M}$ by being added to HAN solutions of concentrations varying from $0-1 \mathrm{M}$. The test results indicate:

- No decomposition of HAN was observed at the test conditions

- The heat of mixing slightly decreases at HAN concentrations less than $0.05 \mathrm{M}$ 


\section{INTRODUCTION}

Several cold feed tanks in FB-Line and F-Canyon contain HAN/Nitric acid at various concentrations. In preparing these cold feed solutions, strong nitric acid is added directly to the weak HAN solution. Recent information issued as a result of the Hanford incident indicated that this practice may not be advisable. In order to determine the level of hazard associated with this cold feed solution preparation routine, SRTC was asked to study simulated Separations cold feed makeup procedures.

HAN is stable at ambient temperatures and at low nitric acid concentrations. If the nitric acid concentration increases, either by evaporation of water from a tank or by the addition of concentrated acid, an autocatalytic decomposition of the HAN may occur. The reaction generates gas as follows (Refs. $1 \& 2$ ):

$4\left(\mathrm{NH}_{2} \mathrm{OH}\right) \mathrm{HNO}_{3} \rightarrow 3 \mathrm{~N}_{2} \mathrm{O}+2 \mathrm{HNO}_{3}+7 \mathrm{H}_{2} \mathrm{O}$

The rapid gas generation would increase the tank pressure and could adversely affect the integrity of a tank as in the incident at Hanford (Refs. 3 \& 4).

The autocatalytic reaction is exothermic, thus allowing the use of a calorimeter to measure the energy change involved in the reaction.

\section{EXPERIMENTS}

In this study, experiments on the autocatalytic decomposition of HAN at various nitric acid concentrations were conducted. The Parr ${ }^{\circledR} 1455$ solution calorimeter shown below was used to measure the onset of the HAN/Nitric acid reaction. Measurements were made at room temperature and atmospheric pressure.

\section{Parr ${ }^{\circledR} 1455$ Solution Calorimeter}

\section{A) Calorimeter Components}

1 Dewar

$2 \quad$ Rotating cell

3 Teflon dish

4 Push rod

5 Thermistor probe for temperature measurement

6 Air can

7 Drive belt

8 Motor

9 Digital display

10 Front panel keys for special commands and program controls of the operation 
W.B. Van-Pelt

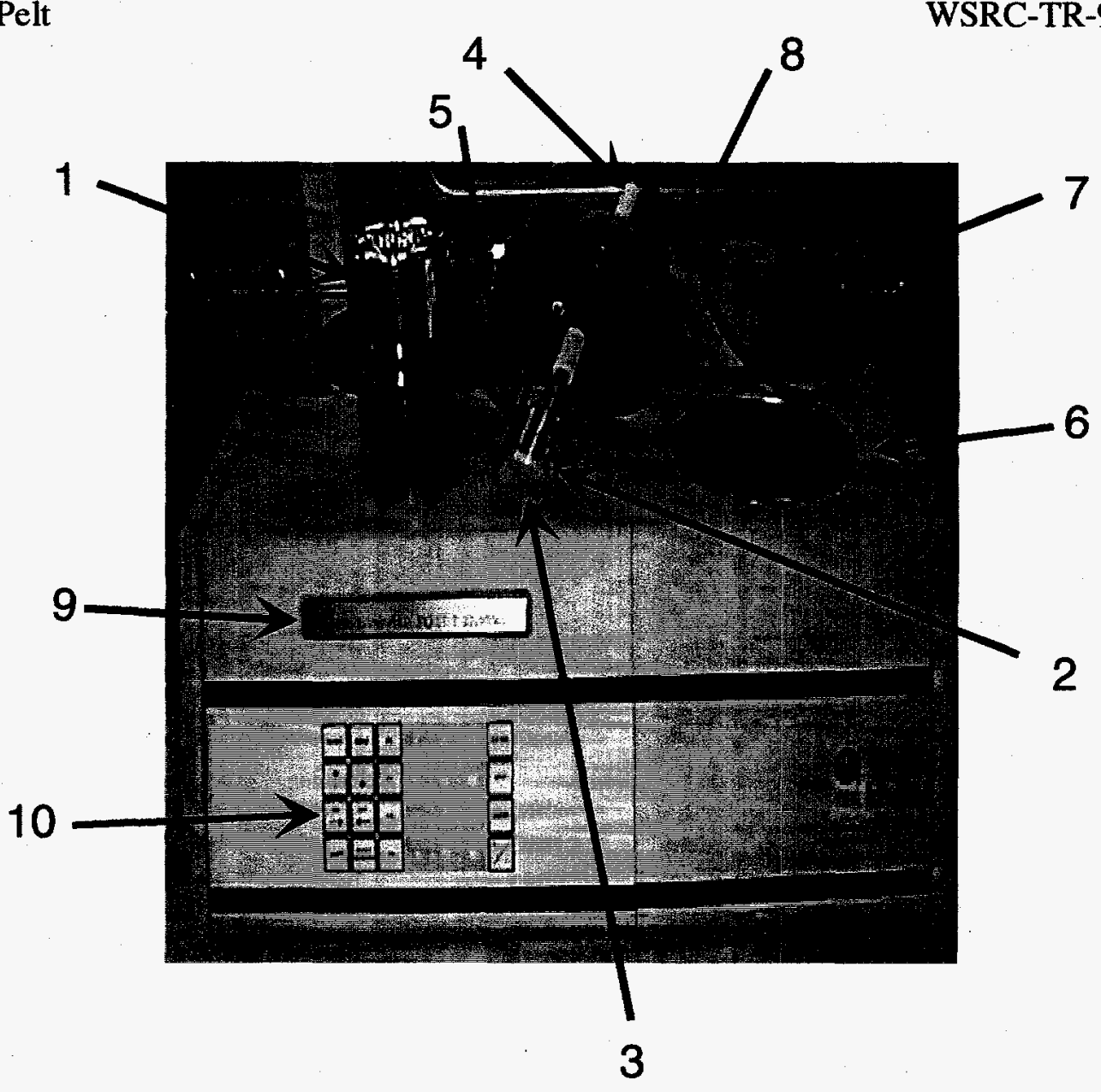

B) Calorimeter In Operation

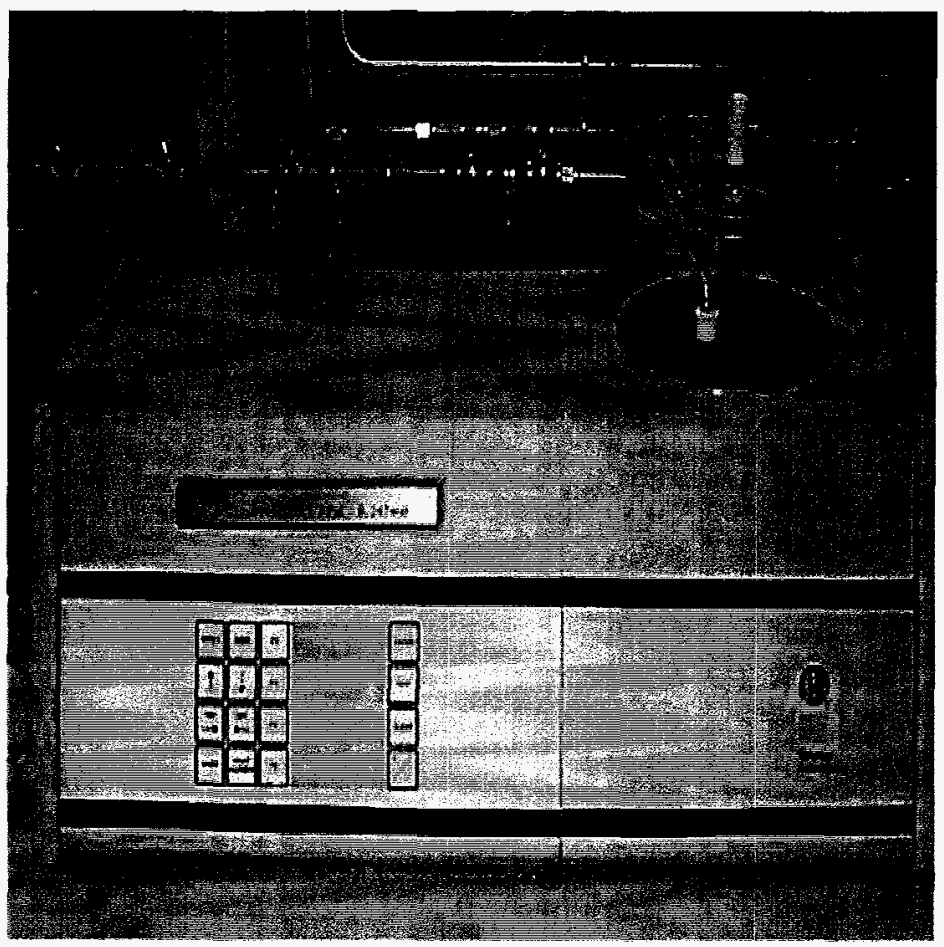

- Page 3 of 10 - 
Test Matrix

To cover the range of cold feed solutions used in Separations operation, the test matrix consists of the following concentrations:

\begin{tabular}{ll} 
& \multicolumn{1}{c}{ Concentration } \\
64Wt\% Nitric Acid & $0.1 \mathrm{M}, 0.25 \mathrm{M}$ and $0.5 \mathrm{M}$ \\
HAN & $0.0 \mathrm{M}, 0.05 \mathrm{M}, 0.1 \mathrm{M}, 0.2 \mathrm{M}, 0.4 \mathrm{M}$, \\
& $0.7 \mathrm{M}$, and $1.0 \mathrm{M}$
\end{tabular}

Concentrations given are the final concentration of each constituent in the combining HAN/nitric acid solution. Appendix A shows how amounts of nitric acid and HAN are determined to provide the desired concentrations of the combining HAN/nitric acid solution. The 0.0M HAN concentration tests are to provide the base-line data. Tests were duplicated at each concentration.

Currently, 64Wt\% nitric acid is used by FB Line, while F Canyon uses 50Wt\% nitric acid. In this test program, $64 \mathrm{Wt} \%$ nitric acid was selected to provide a more bounding case.

\section{Determining the Energy Change Using a Calorimeter}

The energy change, $Q$, is calculated by multiplying the measured temperature change, $\Delta T$, by the energy equivalent, $\mathrm{e}$, of the calorimeter and its contents.

$$
\mathrm{Q}=(\Delta \mathrm{T})(\mathrm{e}) \quad \text { [Equation 1] }
$$

If $\Delta \mathrm{T}$ is measured in ${ }^{\circ} \mathrm{C}$ and $\mathrm{e}$ is expressed in calories per ${ }^{\circ} \mathrm{C}, \mathrm{Q}$ will be reported in calories.

The change in enthalpy, $\Delta H$, at the mean reaction temperature is equal to $-\mathrm{Q}$ divided by the amount of sample used in the experiment, expressed either in moles of grams.

$$
\Delta \mathrm{H}=-\mathrm{Q} / \mathrm{m} \quad \text { [Equation 2] }
$$

Figure 1 shows a typical calorimetric experiment in which the temperature change is measured allowing the change in enthalpy to be determined. 


\section{Figure 1: Calorimetric Experiment}

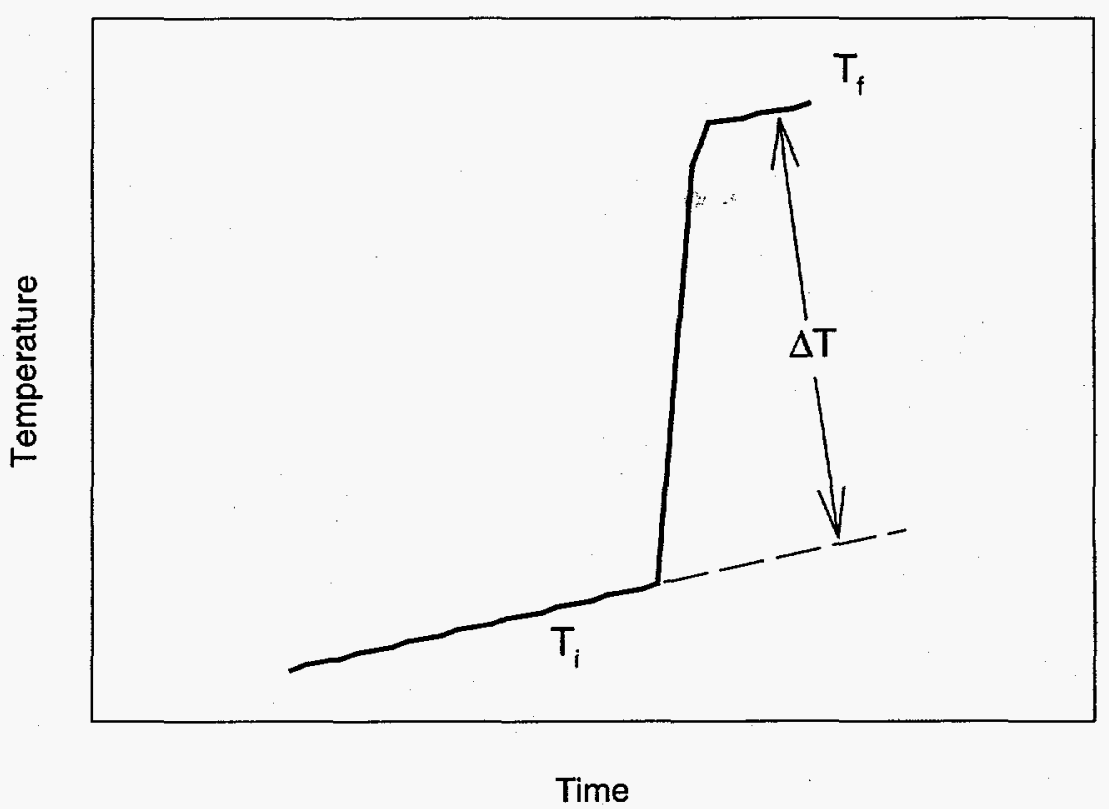

\section{Experimental Procedures}

HAN was supplied by F Canyon. Reagent grade nitric acid was obtained from SRS chemical stores.

Prior to the actual tests, standardization of the calorimeter with tris (hydroxymethyl) aminomethane, commonly called TRIS, was conducted as described in the Operating Instruction Manual (Ref. 5). TRIS was provided by the calorimeter vendor. The standardization determines the energy equivalent value of the calorimeter and its contents which is required to compute the energy change as shown in Equation 1 above.

Measured energy equivalent values vary from 118.522 to $120.753 \mathrm{cal} /{ }^{\circ} \mathrm{C}$ with an average value of $119.7243 \mathrm{cal} /{ }^{\circ} \mathrm{C}$ compared with $121 \mathrm{cal} /{ }^{\circ} \mathrm{C}$ given in the Manual. Upon completion of the tests, the calorimeter was standardized again to yield the values of 118.925 and $118.8 \mathrm{cal} /{ }^{\circ} \mathrm{C}$, indicating a negligible drift of the instrument.

Tests were carried out as follows:

1) Sample of HAN solution was placed in the calorimeter Dewar.

2) After filling, the Dewar was set in the air can.

3) Nitric acid was loaded in the rotating sample cell.

4) The rotating cell with thermistor probe was lowered into the Dewar, immersed in the HAN solution.

5) Drop the drive belt over the pulleys.

6) Start the motor to rotate the cell to begin the test. 
There are three distinct time periods in each test:

1. Preperiod: The reactants (HAN and nitric acid) are allowed to come to thermal equilibrium.

2. Reaction period: The reactants are combined by releasing nitric acid into HAN solution.

Each component in the combining solution has the concentration specified in the test matrix above. The reaction, if any, proceeds to completion under the vigorous stirring action of the rotating cell. An enthalpy change occurs in the system.

3. Postperiod: The calorimeter again comes to thermal equilibrium.

In each test, the calorimeter recorded the solution temperature, determined the energy change according to Equations 1 and 2, and reported the gross heat (or enthalpy change) at the end of the test. A large energy change indicates the onset of the exothermic autocatalytic reaction.

\section{RESU̇LTS}

A series of tests was conducted at the concentrations specified by the test plan. A summary of amounts of nitric acid and HAN used in each test was given in Appendix B. Table 1 summarizes the test results that are plotted in Figure 2. Note that the gross heat is given in calories per gram of pure nitric acid.

The results show a low energy change of the combining HAN/nitric acid solution. At the highest test concentration (i.e. $0.5 \mathrm{M} \mathrm{HNO}_{3}$ and $1 \mathrm{M} \mathrm{HAN}$ ), a gross heat of $41.7 \mathrm{cal}$ per gram of nitric acid was measured, which is equivalent to $13.7 \mathrm{cal}$ per gram of HAN. This value is much less than the theoretical maximum heat of $511 \mathrm{cal} / \mathrm{g}$ or $49.1 \mathrm{kcal} / \mathrm{mole}$ of HAN (Ref. 6). The measured heat of reaction studied at Hanford ranges from about 77 to $194 \mathrm{cal} / \mathrm{g}$ of HAN at initial test concentrations larger than $1.5 \mathrm{M}$ for nitric acid and $0.8 \mathrm{M}$ for HAN and at temperatures greater than $37^{\circ} \mathrm{C}$. Therefore, the heat change measured at the concentration conditions in this study is likely due to mixing rather than decomposition of HAN. Figure 2 also indicates that the heat of mixing slightly decreases at HAN concentrations less than $0.05 \mathrm{M}$

\section{Table 1: Result Summary}

\begin{tabular}{|c|c|c|c|}
\hline $\begin{array}{c}\text { HAN Concentration } \\
(\mathrm{mol} / \mathrm{L})\end{array}$ & \multicolumn{3}{|c|}{$\begin{array}{c}\text { Gross Heat } \\
\text { (cal/g of HNO }) \\
0.25 \mathrm{M} \mathrm{HNO3}\end{array}$} \\
\hline 0 & $0.1 \mathrm{M} \mathrm{HNO3}$ & $0.5 \mathrm{M} \mathrm{HNO3}$ \\
\hline 0.05 & 36.30 & 34.12 & 35.34 \\
\hline 0.1 & 33.43 & 34.06 & 35.23 \\
\hline 0.2 & 33.25 & 35.52 & 36.26 \\
\hline 0.4 & 33.85 & 36.63 & 37.05 \\
\hline 0.7 & 36.05 & 37.04 & 38.42 \\
\hline 1.0 & 38.19 & 39.64 & 40.21 \\
\hline & 40.96 & 41.75 & 41.69 \\
\hline
\end{tabular}




\section{Figure 2: HAN/Nitric Acî̀d Test Results}

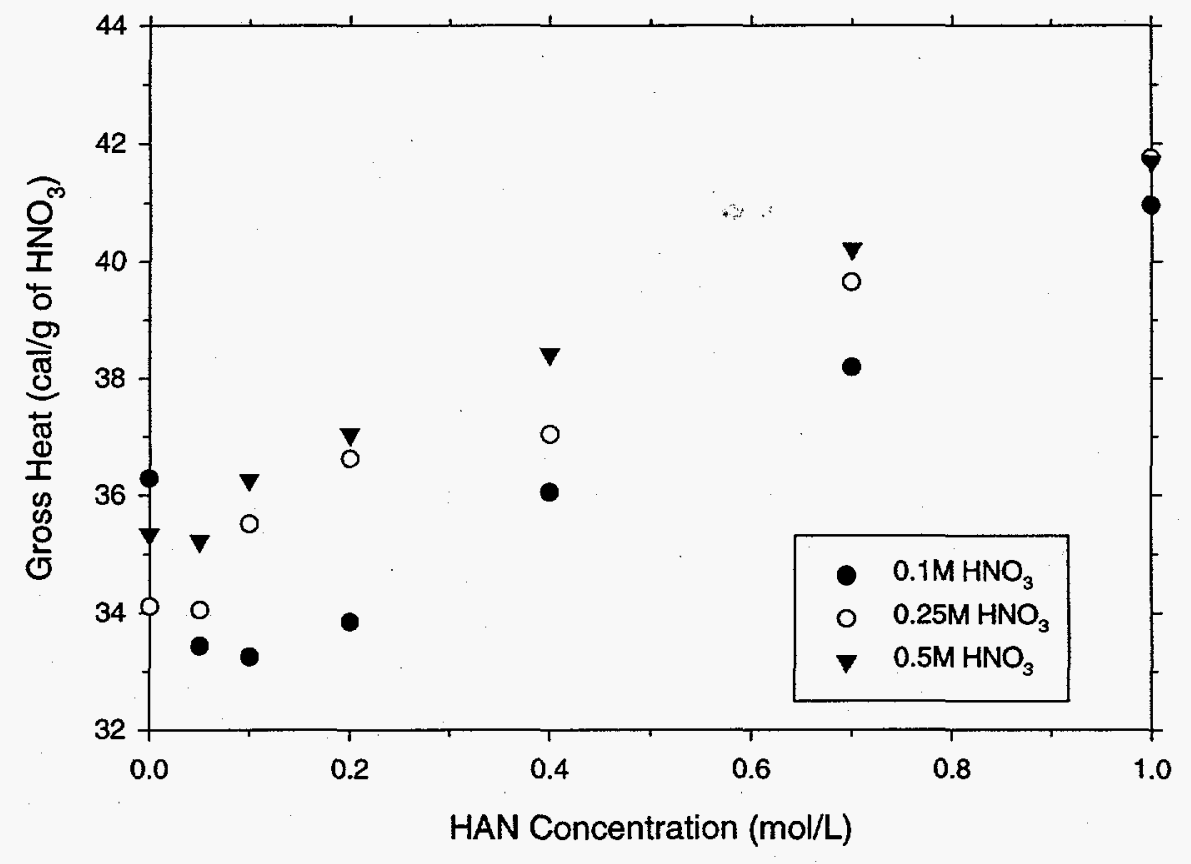

\section{CONCLUSIONS}

Examination of the data obtained in this study results in the following conclusions:

- No HAN decomposition was observed at the test conditions, indicating Separations' practice of preparing cold feed solutions by adding strong acid to weak HAN solutions appears to be safe and acceptable.

- This study does not address the effect of mixing. If the solution is not well-mixed, it may be possible for localized pockets of unmixed HAN and nitric acid to gather and vigorously react. This attribute could be evaluated by CFD modeling.

\section{QUALITY ASSURANCE}

All experimental work was conducted in accordance with established procedures specified by Conduct of Research and Development Savannah River Technology Center (WSRC-IM-9700024). Experimental results and calculations were recorded in the official laboratory notebook (WSRC-NB-98-00114).

\section{REFEFENCES}

1. Hodges, M.E. "Pressure Considerations for FB-Line Tanks Containing Hydroxylamine Nitrate," X-CLC-F-00134, 1997.

2. Hodges, M.E. "Pressure Considerations for Tanks Containing Hydroxylamine Nitrate," XCLS-C-00002, 1997. 
3. Barney, G.S. "Status Report on Laboratory Investigation of Tank A-109 Explosion," B\&W Hanford Co., Letter to M.J. Gibson, 15F00-97-061, June 9, 1997.

4. Fauske, H. "Some Additional Comments on the Tank A-109 Explosion," Memo to Ron Gerton, June 11, 1977.

5. "Parr 1455 Solution Calorimeter - Operating Instruction Manual," No. 281MM.

6. Barney, G.S. "Laboratory Investigation of Chemical Reactions That Resulted in Tank A-109 Explosion," B\&W Hanford Co., Letter to M.J. Gibson and E.M. LaRock, 15F00-97-092, July 31, 1997. 


\section{Appendix A :- \\ Sample Calculation of HAN and Nitric Acid Test Amounts}

Test concentrations: $0.1 \mathrm{M} \mathrm{HNO}_{3}$ and $1 \mathrm{M} \mathrm{HAN}$

Properties:

$$
\begin{array}{ll}
64 \mathrm{Wt} \% \mathrm{HNO}_{3}: & \mathrm{MW}=63.02 \\
& \text { Spec. Gravity }=1.3795 @ 25^{\circ} \mathrm{C} \\
1.77 \mathrm{M} \text { or } 16 \mathrm{Wt} \% \mathrm{HAN}: & \mathrm{MW}=96.04 \\
& \text { Spec. Gravity }=1.08518
\end{array}
$$

Density of the combining HAN/nitric acid solution is calculated by the following correlation provided by E.A. Kyser:

Hence:

$$
\mathrm{SG}=1.002+\left(0.03096 \mathrm{C}_{\mathrm{HNO} 3}+0.0354 \mathrm{C}_{\mathrm{HAN}}\right) \quad \mathrm{C}_{\mathrm{HNO} 3}, \mathrm{C}_{\mathrm{HAN}} \text { in } \mathrm{mol} / \mathrm{L}
$$

$$
\mathrm{SG}=1.040496
$$

A total test volume of $120 \mathrm{~mL}$ is selected for the HAN/nitric acid solution. At the condition of $0.1 \mathrm{M} \mathrm{HNO}$ and $1 \mathrm{M} \mathrm{HAN}$ the $120 \mathrm{~mL}$ solution contains $0.75624 \mathrm{~g}$ nitric acid and $11.5248 \mathrm{~g}$ HAN. To obtain the required test concentrations the following mix will be needed:

$$
\begin{array}{ll}
\text { 64Wt\% HNO3: } & (0.75624 \mathrm{~g} / 0.64)=1.181625 \mathrm{~g} \\
\text { 16Wt\% HAN: } & (11.5248 \mathrm{~g} / 0.16)=72.03 \mathrm{~g} \\
\text { Additional Water: } & (120 \mathrm{~mL})(1.040496 \mathrm{~g} / \mathrm{mL})-(1.181625 \mathrm{~g}+72.03 \mathrm{~g})=51.6479 \mathrm{~g}
\end{array}
$$

Test Procedure:

Step 1: Place $72.03 \mathrm{~g}$ HAN with $51.6479 \mathrm{~g}$ water in the Dewar.

Step 2: Place $1.181625 \mathrm{~g}$ HNO3 in the rotating sample cell. 
Appendix B

HAN and Nitric Acid Sample Amounts

\begin{tabular}{|c|c|c|c|c|}
\hline $\begin{array}{c}\text { HNO3 Conc. } \\
(\mathrm{mol} / \mathrm{L})\end{array}$ & $\begin{array}{c}\text { HAN Conc. } \\
(\mathbf{m o l} / \mathbf{L})\end{array}$ & $\begin{array}{c}\text { 64Wt\% HNO3 } \\
\text { Amount } \\
(\mathbf{g})\end{array}$ & $\begin{array}{c}\text { 16Wt\% HAN } \\
\text { Amount } \\
(\mathbf{g})\end{array}$ & $\begin{array}{c}\text { Water Amount } \\
\text { (g) }\end{array}$ \\
\hline 0.1 & 0 & 1.181625 & 0 & 119.4299 \\
\hline 0.1 & 0.05 & 1.181625 & 3.6015 & 116.0408 \\
\hline 0.1 & 0.1 & 1.181625 & 7.203 & 112.6517 \\
\hline 0.1 & 0.2 & 1.181625 & 14.406 & 105.8735 \\
\hline 0.1 & 0.4 & 1.181625 & 28.812 & 92.3171 \\
\hline 0.1 & 0.7 & 1.181625 & 50.421 & 71.9825 \\
\hline 0.1 & 1.0 & 1.181625 & 72.03 & 51.6479 \\
\hline 0.25 & 0 & 2.954063 & 0 & 118.2147 \\
\hline 0.25 & 0.05 & 2.954063 & 3.6015 & 114.8256 \\
\hline 0.25 & 0.1 & 2.954063 & 7.203 & 111.4365 \\
\hline 0.25 & 0.2 & 2.954063 & 14.406 & 104.6583 \\
\hline 0.25 & 0.4 & 2.954063 & 28.812 & 91.10194 \\
\hline 0.25 & 0.7 & 2.954063 & 50.421 & 70.76734 \\
\hline 0.25 & 1.0 & 2.954063 & 72.03 & 50.43274 \\
\hline 0.5 & 0 & 5.908125 & 0 & 116.1895 \\
\hline 0.5 & 0.05 & 5.908125 & 3.6015 & 112.8004 \\
\hline 0.5 & 0.1 & 5.908125 & 7.203 & 109.4113 \\
\hline 0.5 & 0.2 & 5.908125 & 14.406 & 102.6331 \\
\hline 0.5 & 0.4 & 5.908125 & 28.812 & 89.07668 \\
\hline 0.5 & 0.7 & 5.908125 & 50.421 & 68.74208 \\
\hline 0.5 & 1.0 & 5.908125 & 72.03 & 48.40748 \\
\hline & & & & \\
\hline
\end{tabular}

